\title{
イモゾウムシ卵のエタノール浸漬による人工飼料のバクテリア污染抑制： 卵をファーセレラン水溶液とともに飼料に接種した場合
}

\author{
大野＼cjkstart豪・佐々木智基・小濱 継雄 \\ (沖縄県ミバエ対策事業所)
}

\begin{abstract}
Suppression of bacterial contamination of artificial diet by ethanol submersion of eggs of the West Indian sweetpotato weevil, Euscepes postfasciatus (Fairmaire) (Coleoptera:Curculionidae), before planting eggs suspended in furcellaran solution on the diet. Suguru Ohno, Tomonori Sasaki and Tsuguo Kohama (Fruit Fly Eradication Project Office, Okinawa Prefectural Government, Naha, Okinawa 902-0072, Japan)
\end{abstract}

We tested the suppression of bacterial contamination of artificial diet by 5 -min submersion of Euscepes postfasciatus eggs in $70 \%$ ethanol before a simple egg-seeding method that is used for mass-rearing of other weevil species. In this egg-seeding method, eggs are suspended evenly in a sterile furcellaran solution (a viscous liquid); the mixture is then dropped onto the surface of the diet. When weevil eggs rinsed only with sterile water were mixed with the solution and placed on the diet, bacterial colonies formed in all replicates within 3 days. Ethanol treatment of the eggs before mixing with the solution significantly reduced and delayed formation of bacterial colonies on the surface of the diet by $29 \%$ and $8 \mathrm{~d}$, respectively. However, these values were significantly less than those achieved by an ordinary egg sterilization method (20-min submersion in $5 \%$ formaldehyde; $71 \%$ and $13 \mathrm{~d}$ ). Therefore, it appears that ethanol treatment of $E$. postfasciatus eggs alone is insufficient for preventing bacterial contamination of diet in the massrearing of $E$. postfasciatus.

Key words : bacteria, egg-surface sterilization, ethyl alcohol, mass-rearing, moisture, quarantine pest

緒言

沖縄県では，植物防疫法により特殊病害虫に指定され ているイモゾウムシ Euscepes postfasciatus (Fairmaire) (甲虫目：ゾウムシ科）の，不妊虫放飼法による根絶防 除のため, 人工飼料を用いた本種の大量増殖法の開発が 進められている（山崖・下地，2000）。昆虫類の人工飼 育では一般に，バクテリアやカビの発生による飼料の污 染を防ぐための方法のひとつとして，ホルマリン等を用 いた卵の表面殺菌が行われる(晹島ら、1991： Sikorowski and Lawrence, 1994)。イモゾウムシの人工 飼育に执いて，表面殺菌が施されていない卵を人工飼料 に接種した場合，接種後数日以内に鸰料表面にバクテリ アの発生が認められる(下地，2003）。一方, 卵を5\% ホルマリンに20分浸漬したのち接種を行うと，畩化率を 低下させることなく，飼料のバクテリア発生を接種後平 均20日間にわたって抑制し，飼育虫の生存率を有意に上
昇させることができる（下地，2003）。

昆虫類の卵の表面殺菌に扮いて, 卵が殺菌液になじみ にくい場合には，70\%エタノール浸漬による前処理が行 われることがある（湯島ら，1991）。イモゾウムシの卵 は水になじみやすいため前処理は必要とされないが，最 近の研究から, エタノールは本種卵の殺菌液としても使 用可能であることが示された。下地（2003）は，70\%工 タノールに30秒から 5 分間浸漬した卵を人工飼料に接種 して7 日間観察を行い, 孵化率の低下と飼料表面のバク テリア発生は認められないことを示した。大野ら （2004）は，70\%エ夕ノールに5分浸漬（以下，エ夕 ノール处理）したイモゾウムシ卵の邲化後の生存・発育 が，5\%ホルマリンに20分浸漬（以下，ホルマリン処理） したものに比べて棌色ないことを明らかにした。下地 (2003) では，エタノール処理・ホルマリン処理間での バクテリア污染抑制力の比較はなされていないが，大野 ら（2004）は, 約 2 ヶの試験期間を通じて, エ夕ノー 
ル処理区とホルマリン处理区の人工瞲料のどちらにもバ クテリアの発生が観察されなかった事実から，これら 2 つの処理が同等のバクテリア污染抑制能力をもつと考え た。

下地（2003）抢上び大野ら（2004）において，飼料へ の卵の接種は，殺菌後自然乾燥させた卵を，面相筆を用 いて互いに接しないように飼料表面に並べることによっ て行われた。筆を用いた卵接種は時間と手間がかかるた め, 現在我々は, イモゾウムシと同じゾウムシ科に属す るワタミゾウムシ Anthonomus grandis (Boheman) の 大量增殖に採用された卵接種法 (Sikorowski et al., 1984）をイモゾウムシの人工飼育に導入するための試験 を進めている。この方法では，卵を海草由来の增粘安定 剤の一種であるファーセレラン（furcellaran）の水溶液 と混合して水溶液中に均一に分布させた後, 溶液ごと卵 を人工飼料表面に接種する。イモゾウムシ卵のエタノー 儿処理が、この大量增殖向けの接種法を用いた場合でも， 十分なバクテリア抑制効果をもつかは明らかでない。そ こで本研究では，イモゾウムシのエタノール処理卵，木 ルマリン処理卵および無処理卵を，ファーセレラン氷溶 液に混合して人工飼料に滴下し，飼料のバクテリア污染 を調ベた。

本文に入るに先立ち，実験を手伝って下さった沖縄県 ミバ工対策事業所の青野恵美氏に扮礼申し上げる。

\section{材料および方法}

1994年 8 月に沖縄県読谷村で採集し， $25 \pm 1^{\circ} \mathrm{C}, 14 \mathrm{~L}$ ： 10D の条件下でサッマイモ塊根を用いて累代飼育してい るイモゾウムシ個体群（年当たり 5 世代）より，2003年 3 月から 5 月にかけて塊根から自然脱出した成虫をひと まとめにして採卵に用いた（採卵法については大野ら，

2004を参照)。卵はろ紙を敷いたプラスチックシャーレ

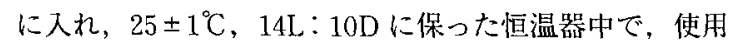
するまで保管した。大野ら（2004）に従い，卵の表面殺 菌および飼料への接種には 6 日齢の卵を用いた。これら の卵から，メスピペットを用いた卵数推定法（大野豪 ら，未発表）により約5,000個の卵群を 3 群用意した。

これら 3 群のそれぞれに対し，70\%エタノール処理， $5 \%$ ルマリン処理，および対照区として隇菌水で 2 度 すすぐだけの処理のいずれかを行っだロタノールとホ ルマリンへの浸漬時間はそれぞれ 5 分および20分とした (下地，2003；大野ら，2004）。浸漬中は約 1 分沶きに容 器を軽く摇らして摚拌し, 浸漬後の卵は滅菌水で 2 度す すいだ。浸漬する殺菌液およびすすぎに用いる滅菌水の 量はいずれも 1 回につき $100 \mathrm{ml}$ とした。処理後の卵は,

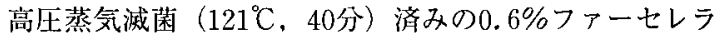
ン水溶液（蒸留水とファーセレラン粉末 [伊那食品工 業]を重量比500：3で混合したもの）に $1 \mathrm{ml}$ 当たり的 100卵を含むように混合し，卵を溶液中に均一に拡散す るために溶液をよく摚拌した。それぞれの処理区に対し， イモゾウムシ幼虫の大量增殖用に開発した防腐郕入りの 人工飼料 (Shimoji and Yamagishi [2004] の飼料と同一 原料を用い，上り簡易な方法で作製したもの；上里卓 己・小濱継雄，末発表）が約 $23 \mathrm{~g}$ (範囲22-24 g) 入った 直径 $9 \mathrm{~cm}$ の滅菌済みガラスシャーレを15個ずつ用意し た。それぞれのシャーレの飼料表面に，卵を含んだ ファーセレラン水溶液を $1 \mathrm{ml}$ ずつ, 滅菌済みチップ (卵が詰まらないよう先端から $2 \mathrm{~mm}$ 程度を切り落とし たもの）を装着したマイクロピペットを用いて滴下した。 接種後のシャーレは, 蓋と本体の隙間をセロハンテープ で目張りしたのち，上記と同じ恒温器中に保管した。

接種の翌日から 35 日後まで每日飼料表面を観察し， シャーレごとのバクテリア発生日を記録した。人工飼料 表面に肉眼で認識できる大きさのコロニー（下地，2004 を参照) が初めて観察された日をバクテリア発生日とし た。少数のシャーレに扔いて，セロハンテープで目張り した部分に発生したカビが内部に侵入して飼料表面を覆 い, バクテリア発生の確認が困難になったため,これら のシャーレは分析から除外した。観察終了後, 各处理区 におけるバクテリア発生率（バクテリア発生が観察され たシャーレ数/カビが発生したシャーレをのぞく全 シャーレ数）扔よびバクテリア発生までの平均日数を算 出した。

\section{結果および考察}

バクテリア発生率と発生までの平均日数を Table 1 に 示した。殺菌処理をしていない卵を接種した対照区では, 全てのシャーレにおいて接種から 3 日後にバクテリア発 生が観察された。エ夕ノール処理区では71.4\%のシャー レ（14個中 10 個）で接種から平均7.8日後に, ホルマリ ン処理区では $28.6 \%$ のャーレ（14個中 4 個）で接種か ら平均13.3日後に観祭された。バタテリア発生率执よび バクテリア発生までの平均日数の双方とも， 3 処理区の すべての組み合わせ間で有意に異なった $(P<0.05$ ；発 生率: Ryan の多重範囲梌定; 平均日数: 対数変撸後の デー夕に対する Tukey - Kramer の HSD 検定)。

以上の結果から，イモゾウムシ卵のエタノール処理は， ファーセレラン水溶液による卵接種法を用いた場合にお いても，人工飼料のバクテリアの增殖を抑制し遅延させ る効果があるものの，その效果はホルマリン処理のそれ 
Table 1. Bacterial contamination of larval artificial diet after seeding of Euscepes postfasciatus eggs submerged in $70 \%$ ethanol for $5 \mathrm{~min}$ or in $5 \%$ formaldehyde for $20 \mathrm{~min}^{\text {a) }}$

\begin{tabular}{lccc} 
& \multicolumn{3}{c}{ Egg-surface treatment } \\
\cline { 2 - 4 } & Control $^{b /}$ & Ethanol & Formaldehyde \\
\hline No. of contaminated Petri dishes / No. of tested Petri & $15 / 15$ & $10 / 14$ & $4 / 14$ \\
dishes $(\%)^{c}$ & $(100)$ & $(71.4)$ & $(28.6)$ \\
Days to observation of bacteria (mean \pm SD) ${ }^{\text {d) }}$ & $3.0 \pm 0.0$ & $7.8 \pm 4.5$ & $13.3 \pm 2.5$ \\
[range] & {$[3]$} & {$[5-20]$} & {$[12-17]$} \\
\hline
\end{tabular}

a) One milliliter of sterile $0.6 \%$ furcellaran solution containing approximately 100 eggs was dropped into a Petri dish filled with 23g of artificial diet (a modified version of Shimoji and Yamagishi's [2004] diet: $T$. Uesato and T. Kohama, unpublished), and bacterial colony formation was visually inspected daily for 35 days. Fifteen Petri dishes were used for each treatment. Dishes contaminated by fungus were excluded from the statistical analyses. b) Eggs rinsed only with sterile water. c) Contamination ratio varied significantly among all pairs of treatments (Ryan's multiple-range test, $P<0.05$ ). d) Mean days varied significantly among all pairs of treatments (Tukey-Kramer's HSD test on $\log _{10}$-transformed data, $P<0.05$ ).

よりも弱いことが示された。

下地（2003）は，エ夕ノール処理卵を筆を用いて人工 飼料に接種した後，7日間に渡ってバクテリア発生が観 察されなかったことから，エタノールは本種の卵表面の 殺菌液として十分に使用可能であると考えた。大野ら (2004)は，同様な処理卵を同様に飼料に接種した後, すべての成虫の羽化が終丁するまでの間（63日間），バ クテリア発生が観察されなかったことを報告している。 しかし，大量増殖を想定した卵接種法を採用した本研究 では，エタノール处理区のバクテリア発生率は $71 \% に の$ ほり，発生の過半数（10シャーレ中 6 個）は接種後 7 日 以内に観察された。このため、卵の70\%エタノール5 分 浸漬処理は, 単独ではイモゾウムシの大量增殖における 飼料のバタテリア污染抑制法として不十分であると考え られる。

ホルマリン処理区の少数のシャーレにみられたバクテ リア発生もまた，下地（2003）の場合（接種から平均20 日）より早く，すべて接種から17日以内 (Table 1) に 観察さ机た。本研究の結果は,ファーセレラン水溶液を 用いた卵接種法が，従来の筆を用いた接種法よりも，バ クテリアの增殖に好適な環境をもたらしていることを示 唆している。ファーセレラン水溶液の滴下により, 飼料 表面が湿った状態に保たれることが，バクテリアの增殖 に都合がよい可能性がある。もしこの考えが正しければ, 水溶液の滴下後に, 飼育容器の通気性を保つなどして飼 料表面を乾燥させれば，バクテリアの增殖をいくらか抑 制することができるであろう。また，エ夕ノールとホル マリンを組み合わせた使用や殺菌液への浸漬時間の延長 により，バクテリア污染抑制効果が向上する可能性も考 えられる。ただし，殺菌液の複数使用や浸漬時間の延長 がイモゾウムシの瞬化や発育に及ぼす影響については明
らかでなく，今後調べる必要がある。

\section{摘要}

イモゾウムシ人工飼料のバタテリア活染防止法として の有効性が最近確かめられた，70\%エタノール5分間の 卵浸漬処理が、他種ゾウムシの大量増殖に導入された簡 易な卵接種法を使用した場合にも効果を示すかを調べた。 この方法では，卵はファーセレラン水溶液という粘度の ある液体に混合され，水溶液ごと飼料表面に滴下される。 エタノール処理したイモゾウムシ卵を滅菌済みファーセ レラン水溶液と混合して飼料に接種すると, 滅菌水です すいだたけけ卵を同水溶液と混合して接種した場合に比 ベ，飼料のバクテリア発生率抢よびバクテリア発生まで の日数を有意に低下・逮延させることができた。しかし， 卵をエタノール処理した場合でも，バクテリア発生率は 71\%にのぼり，従来のイモゾウムシ卵の殺菌法（5\%ホ ルマリンに20分浸漬）と比べると，発生率の低下・発生 までの日数の遅延の程度は有意に弱かった。このため, 卵の70\%エタノール 5 分処理は, ファーセレラン水溶液 を卵接種に使用する場合には，単独では飼料のバクテリ ア污染抑制法として不十分であると考えられた。

\section{引 用 文 献}

大野 豪・佐々木智基・浦崎貴美子 -小濱継雄 (2004) エタノールによる卵表面処理がイモゾウムシの脬化後 の生存・発育に及ほす影響. 九病虫研会報 50：40-43. 下地幸夫（2003）イモゾウムシの卵接種が起因となる人 工幼虫飼料污染の防止. 沖縄農業 37:57-60.

下地幸夫（2004）サッマイモ害虫イモゾウムシの人工飼 育法. 沖縄県特殊病害虫特別防除事業特別研究報告第 3 号、沖縄県ミバ工対策事業所 (那覇), pp. 73. 
Shimoij, Y. and M. Yamagishi (2004) Reducing rearing cost and increasing survival rate of West Indian sweetpotato weevil, Euscepes postfasciatus

(Fairmaire) (Coleoptera: Curculionidae) on artificial larval diet. Appl. Entomol. Zool. 39 : 41-47.

Sikorowski, P. P., J. G. Griffin, J. Roberson and O. H. Lindig (1984) Boll Weevil Mass Rearing Technology. University Press of Mississippi (Jackson), pp. 172.
Sikorowski, P. P. and A. M. Lawrence (1994) Microbial contamination and insect rearing. Am. Entomol. 40: 240-253.

山岸正明・下地幸夫（2000）不妊虫放飼法によるゾウム シ類の根絶（7）イモゾウムシの大量増殖・不奼化・ マーキング・輸送・放飼. 植物防疫 $54: 476-478$.

湯島 健・釜野静也・王木佳男（編）（1991）昆虫の飼 育法. 日本植物防疫協会 (東京), pp. 392 . 